\title{
Analysis on the Influence of Inflation on Financial Markets and Institutions in China
}

\author{
Xin Tang* \\ Nanjing Foreign Language School, Nanjing, Jiangsu Province, 210003, China \\ *Corresponding author. Email: cindytangxin@icloud.com
}

\begin{abstract}
Impacts of inflation on financial markets and institutions in China will be discussed in this article, focusing on the stock markets and commercial banks. Since many scholars have studied how financial development affects inflation, the author chose to carry out reverse research. After comparing the average annual CPI and Shanghai Composite Index from 2000 to 2020, the author found that the annual earnings of the stock market will increase in lockstep with a rise in inflation which is relatively low and stable. After inflation goes too high, exceeding a certain value, will be detrimental to the stock market. When studying inflation's effects on commercial banks, theoretical analysis was used. The disequilibrium between demand and supply of credit funds will be brought by inflation, and both revenue and costs of raising funds in commercial banks will decrease. Also, liquidity risk will be caused by the mismatch of deposits and loans maturity. In the end, several suggestions will be given to the public and commercial banks.
\end{abstract}

Keywords: Inflation, financial market, financial institution, stock market, commercial bank

\section{INTRODUCTION}

As figure 1 shown, since 2000, China has experienced two periods of severe inflation, from 2007 to 2008,2011 to 2012, respectively. Inflation in 2007 was caused by international investors who bought up $\mathrm{RMB}$, waiting for it to appreciate, while the inflation in 2011 was mainly triggered by excessive money in circulation though the reserved ratio was increased to approximately $22 \%$ by central banks back then [6]. Meanwhile, financial performance in China changed obviously. Is there any relationship between inflation and financial development? After reading some articles, the author found that many scholars have studied the impacts of financial advancement on inflation, but few of them have conducted the opposite research. Therefore, the author decided to focus on the effects of inflation on financial performance in China.

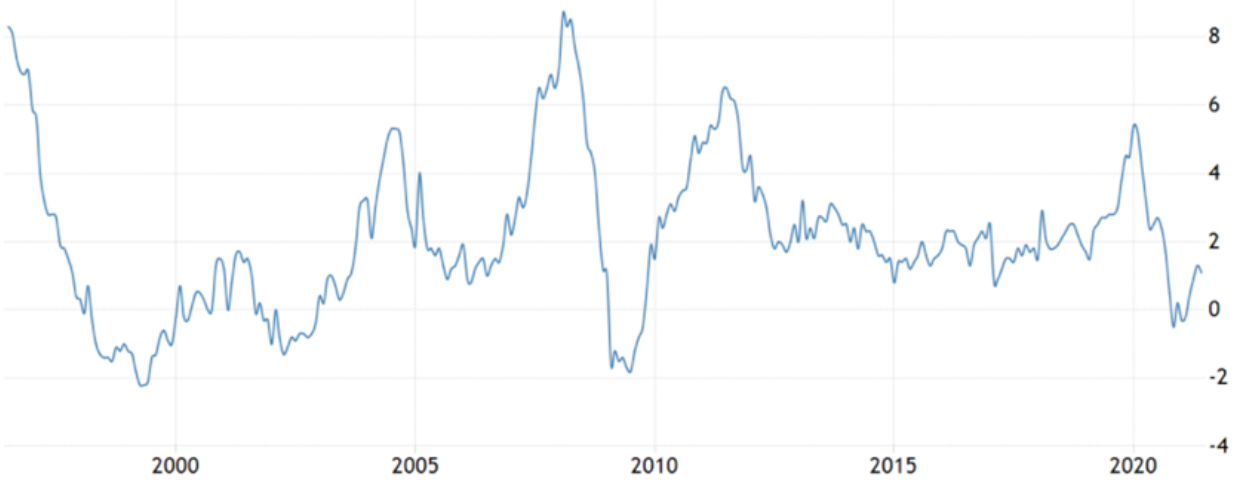

SOURCE: TRADINGECONOMICS. COM I NATIONAL BUREAU OF STATISTICS OF CHINA

Figure 1. Inflation rate in China from 2000 to 2020 (China-Inflation Rate, 2021) [1].

The financial structure of a country mainly consists of financial markets, financial institutions, financing activities under various credit modes, and financial assets formed by all kinds of financial activities. Among 
them, financial markets and institutions are the two most common and significant parts, so they were chosen to be research objects. It is worth noticing that, so far, the influences of inflation on the stock market remain controversial, so the author took the stock market as the representative of financial markets to figure out this problem. In addition, financial institutions, consisting of banks, securities companies, insurances, financial leases, and other financial institutions, are worthy of study as intermediaries for financial product transactions in the financial markets. Since commercial banks are ubiquitous in daily lives, they are considered as examples of financial institutions. Consequently, this research objective of this article is to explore the impact of inflation on China's financial markets and financial institutions by using theoretical research and quantitative analysis research methods.

\section{RESEARCH QUESTION ONE: HOW DOES INFLATION AFFECT FINANCIAL MARKETS IN CHINA? (TAKE STOCK MARKET AS AN EXAMPLE)}

Inflation is considered as a signal of the trend of the stock market since it influences fiscal and monetary policies in a country, equity valuations and expectations of investors directly. Normally, contractionary monetary policies including the increased interest rate and decreased money supply will be implemented in central banks in order to ease or even eliminate detrimental effects brought by severe inflation. During this process, prices of stocks will be impacted due to changes in demand and supply of money in the stock market brought by those policies. At present, there are generally two opposite views about how inflation affects the stock market. Some people think that there is a positive relationship between inflation and returns of stock, which means the stock market will be benefited when inflation occurs. Scholars led by Fisher (1930) argued that expected nominal yields of assets are the sum of expected real yields and expected inflation rate [2]. Returns of stock which represents ownership of real assets will increase under inflation, for inflation can lead to a rise in the real economy of a country. Nevertheless, others claim that a negative relationship can be found. According to Fama (1981), a booming economy is signalled by relatively high stock yields. However, a high inflation rate stands for a sluggish economy, and demand for money will be decreased in this case, causing an increase in the inflation rate again. As a result, inflation will impact the stock market adversely.

To figure out this problem, a range of data were collected, including Shanghai Composite Index and consumer price index (CPI) from 2000 to 2020 in China. Comparatively, Shanghai Composite Index lasts longer and has a larger market capacity, so it was chosen to reflect the performance of the stock market. Also, CPI can represent inflation directly as inflation rate $=$ (present CPI-initial CPI) / initial CPI * 100\%. Then, a table was made via data collected.

Table 1. Shanghai Composite Index and average annual CPI between 2000 and 2020 in China (Data came from Shanghai and Shenzhen Stock Exchange and State Statistical Bureau).

\begin{tabular}{|c|c|c|c|c|c|c|c|c|}
\hline Time & $\begin{array}{c}\text { Shanghai } \\
\text { Composite } \\
\text { Index }\end{array}$ & $\begin{array}{c}\text { Average } \\
\text { annual } \\
\text { CPI /\% }\end{array}$ & & & & & & \\
\hline 2000.12 & 2073.47 & 0.4 & 2007.12 & 5261.56 & 4.8 & 2014.12 & 3234.68 & 2.0 \\
\hline 2001.12 & 1645.97 & 0.7 & 2008.12 & 1820.81 & 5.9 & 2015.12 & 3539.18 & 1.4 \\
\hline 2002.12 & 1357.65 & -0.8 & 2009.12 & 3277.14 & -0.7 & 2016.12 & 3103.64 & 2.0 \\
\hline 2003.12 & 1497.04 & 1.2 & 2010.12 & 2808.08 & 3.3 & 2017.12 & 3307.17 & 1.6 \\
\hline 2004.12 & 1266.50 & 3.9 & 2011.12 & 2199.42 & 5.3 & 2018.12 & 2493.90 & 2.1 \\
\hline 2005.12 & 1161.06 & 1.8 & 2012.12 & 2269.13 & 2.7 & 2019.12 & 3050.12 & 2.9 \\
\hline 2006.12 & 2675.47 & 1.5 & 2013.12 & 2115.98 & 2.6 & 2020.12 & 3473.07 & 2.5 \\
\hline
\end{tabular}

As table 1 shown, CPI in China went through an upward trend generally from 2000 to 2007 , and so did Shanghai Composite Index, which means there was a positive relationship between them. Why? There are three main factors that can decide the prices of stocks: performance of listed companies, market capitalization, and confidence of investors for the market. During inflation, an increase in the supply of money drives the price of stocks upwards owing to enough liquidity. Lower financing costs of companies enable them to earn more profits, which also leads to a rise in the price of shares. Besides, capital circumstances boost investors' confidence, causing a boom in the stock market. That is to say, in the initial stage of inflation, increased money supply stimulates demand for shares, so the stock price goes up, which is beneficial to the stock market. However, in lockstep with constantly raised inflation, costs of production for producers and costs of living for residents will rise dramatically, which directly reduces corporations' profits and citizens' living standards. Next, contractionary monetary policies have to be enforced by the authority, so profit margins may be shrunk again with less money supply and higher interest rate, which means the stock market will be influenced negatively. This can be proved by situations in the stock market from 2007 to 2012 when a negative relationship was seen between the Shanghai Composite Index and CPI (the value of CPI peaked at $8.7 \%$ in February of 2008). Then, from 2013 to 2020, positive and negative correlations were alternating frequently according to 
different levels of inflation. Namely, when inflation is low and stable, high stock yields can be provided, which means relatively low inflation will impact the stock market positively, otherwise, the stock market will be affected negatively.

\section{RESEARCH QUESTION TWO: HOW DOES INFLATION AFFECT FINANCIAL INSTITUTIONS IN CHINA? (TAKE COMMERCIAL BANK AS AN EXAMPLE)}

A range of drawbacks for commercial banks will be brought by inflation. For starters, inflation exacerbates the conflict between the source of credit funds and applications of funds. There are two main impacts of inflation on credit funds. First, demand for credit funds will increase considerably. During relatively severe inflation, to maintain the normal development of society, corporations' costs of production will grow in lockstep with rising prices. Also, prices of stocks will fall dramatically due to higher interest rates, so it will be hard for companies to raise money from financial markets directly, which creates a huge demand for funds from commercial banks. Second, a decrease in the stock of money of banks will be found, so credit funds will decrease as well since inflation impedes the transformation from idle funds to loan funds. Normally, a rising rate of prices is greater than that of interest rate in periods of inflation. Consequently, large amounts of idle funds will be invested into speculative activities, for fluctuations in prices make profits of speculation much more than profits from just putting money in banks. As a result, the simultaneous existence of the steep increase in demand for funds and a fall in credit funds in commercial banks will be a serious problem brought by inflation.

In addition, commercial banks may make less revenue during inflation. When the reserve ratio has to be increased to reduce the money supply, commercial banks will provide less loanable funds. Meanwhile, the real interest rate may be decreasing or even be negative although the nominal interest rate is rising (real interest rate $=$ nominal interest rate - inflation rate). For instance, according to the official website of the Bank of China and East Money Information, the benchmark one-year deposit rate in February of 2016 was $1.75 \%$ while CPI back then was $2.3 \%$, so the real interest rate was $-0.55 \%(1.75 \%-2.3 \%)$, which was negative [7] [8]. Under this condition, commercial banks usually use deposits to invest in the stock market and real estate market instead of offering loanable funds to the public. Then, their ability to lending and investing will be reduced owing to less loanable positions.

Nevertheless, inflation does not bring demerits merely. It seems that the costs of raising money for commercial banks increase due to higher interest rates, but inflation actually reduces the costs for them. After enforcing contractionary monetary policies, the deposit interest rate rises a lot. Clients will be less willing to choose products with a long maturity because they predict interest rates will continue to rise in the future, which means people prefer demand deposits compared with fixed deposits. Then, the debt maturity of commercial banks shows a short-term trend, so costs of raising funds for them will decrease relatively. As table 2 shown, during inflation, the percentage of demand deposits in two banks both increase to some extent.

Table 2. Percentages of demand deposit and fixed deposit of personal clients in two commercial banks in China in 2006 and 2007 (Data came from official websites of banks).

\begin{tabular}{|c|c|c|c|c|}
\hline & \multicolumn{2}{|c|}{ China Construction Bank } & \multicolumn{2}{c|}{ Industrial and Commercial Bank of China } \\
\hline & 2006 & 2007 & 2006 & 2007 \\
\hline Demand deposit & $37.5 \%$ & $39.8 \%$ & $31.7 \%$ & $34.7 \%$ \\
\hline Fixed deposit & $62.5 \%$ & $60.2 \%$ & $68.3 \%$ & $65.3 \%$ \\
\hline
\end{tabular}

In general, banks will enter a golden period of raising funds during inflation because the costs will witness a downward tendency. However, in lockstep with the increase in demand deposits, resources of funds become short-term in commercial banks. Then, a mismatch of deposits and loans maturity may be caused, which will lead to liquidity risk in financial institutions.

\section{CONCLUSION}

All in all, the article analyzed the impacts of inflation on financial markets and financial institutions in China, and the stock market and commercial banks were considered as examples. During the research for question one, after conducting quantitative analysis by making tables, results were found: there was a positive relationship between CPI and Shanghai Composite Index from 2000 to 2007, while a negative correlation was found between 2007 to 2012. That is to say, when inflation is low and stable, a rise in it will cause an increase in the stock market's annual earnings, but when inflation continues to grow, surpassing a certain value, the equity market will be affected adversely. Next, by studying how inflation influences commercial banks, several conclusions were drawn. Appearances of both an increase in demand for funds and a fall in credit funds in commercial banks will be brought by inflation. Subsequently, they will be less able to lend and invest owing to less loanable positions, which means commercial banks may make less revenue. However, their costs of raising money will also be reduced since clients will be leaning towards demand deposits which 
have relatively lower interest rates due to expectations for inflation in the future, so whether inflation is profitable for commercial banks is hard to say (profit = revenue - cost). Meanwhile, liquidity risk will be triggered.

Analysis methods in this article are relatively easy, and only a few variables were taken into consideration. For example, when researching how inflation impacts the stock market, the author did not involve exchange rates. Actually, considering the special exchange rate policies in China, the exchange rate is not a representative factor that can affect the stock market. Besides, the certain value of inflation above which the stock market will be influenced reversely was not calculated in this article, so further study including sophisticated equations and models should be conducted to find the precise value and more accurate conclusions.

When inflation is relatively low, people can invest in stocks, but when inflation goes too high, shares are not worth investing in since they are no longer hedges against inflation. For commercial banks, they should carry out strict selection to find suitable targets of offering credit funds. During the period of inflation, different industries will be impacted to different level. Among them, industries with a large proportion of variable costs in total cost will be most affected, such as capital-intensive industries where labor costs will increase sharply. As a result, commercial banks should choose industries whose fixed costs occupy a lot, such as highway industry. Meanwhile, they should come up with some activities to attract clients to deposit, so that they can enjoy relatively low costs of raising funds better and prepare enough sources of funds for future advancement.

\section{REFERENCES}

[1] Trading Economics. China-Inflation Rate [digital image]. 2021. Accessed on 24 July 2021. Available from:

https://zh.tradingeconomics.com/china/inflation-cpi

[2] I. Fisher. The Theory of Interest. Translated by Chen Biaoru. Shanghai: Shanghai People's Publishing House. 1930.

[3] B.X. Xu. Impacts of Inflation on Investing in Shares. Journal of Economics and Law. 2021: 197-198. Accessed on 25 July 2021. Available from: doi: 10.3969/j.issn.1004-8146.2012.3.138

[4] X.B. Zhang. Analysis of Effects of Inflation on Banks. Journal of Economic Forum. Economic Practice, 2008: 104-105.

[5] Y.F. Guo. Impacts of Inflation on Commercial Banks in Our Country and Solutions. Science and Technology in Gansu. 2013, 42(7): 6-8.
[6] East Money information. Reserve Ration in China. 2021. Accessed on 24 July 2021. Available from: http://data.eastmoney.com/cjsj/ckzbj.html

[7] Bank of China. RMB Deposit Rate 2015-10-24. 2021. Accessed on 25 July 2021. Available from: https://www.bankofchina.com/fimarkets/lilv/fd31/2 01510/t20151023_5824963.html

[8] East Money Information. CPI in China. 2021. Accessed on 25 July 2021. Available from: http://data.eastmoney.com/cjsj/cpi.html 